\title{
Beef quality of Nellore steers fed dried or rehydrated and ensiled corn or sorghum grains
}

\author{
Calidad de la carne de Ganado Nelore alimentado con grano de maíz o sorgo seco o rehidratado y \\ ensilado
}

\section{Qualidade de carne de bovinos Nelore alimentados com grãos de milho ou sorgo seco ou reidratado e ensilado}

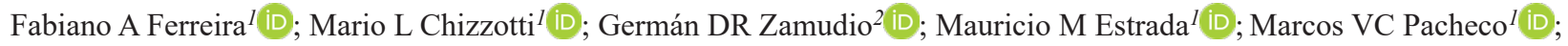 \\ Breno C Silva $^{1}$ D; Sebastião C Valadares-Filho ${ }^{1}$ iD; Rafael TS Rodrigues ${ }^{3 *}$ D.
}

${ }^{1}$ Departamento de Zootecnia, Universidade Federal de Viçosa, Viçosa, MG, 36570-000, Brasil.
2Departamento de Zootecnia, Universidade Federal de Lavras, Lavras, MG, 37200-000, Brasil.
3Departamento de Zootecnia, Universidade Federal do Vale do São Francisco, Petrolina, PE, 56300-000, Brasil.

To cite this article:

Ferreira FA, Chizzotti ML, Zamudio GDR, Estrada MM, Pacheco MVC, Silva BC, Valadares-Filho SC, Rodrigues RTS. Beef quality of Nellore steers fed corn or sorghum grain offered dry or rehydrated and ensiled. Rev Colomb Cienc Pecu 2020; 33(2):121-133.

DOI: https://doi.org/10.17533/udea.rccp.v33n2a04

\begin{abstract}
Background: Rehydration of grains, such as corn and sorghum, is used to increase nutrient absorption. However, the effect of this practice on meat quality is poorly understood. Objective: To evaluate the effects of type of grain and processing on the meat quality of Nellore steers in a feedlot. Methods: Twenty-four non-castrated Nellore steers $(270 \pm 53 \mathrm{~kg}$ initial body weight) were distributed in a completely randomized $2 \times 2$ factorial design, with six replicates. The first factor was cereal type (corn or sorghum), and the second was the grain processing (dry or rehydrated and ensiled). The diets were composed of $30 \%$ corn silage and $70 \%$ concentrate. Sixty days before the beginning of the experiment, corn and sorghum grains were rehydrated and ensiled. The animals were slaughtered after 140 days of confinement. Meat quality analyses were determined in samples of fresh and aged meat (7 days) from the Longissimus lumborum muscle. Results: no difference between treatments was observed for carcass $\mathrm{pH}$ and $\mathrm{L}^{*}$ (lightness), $\mathrm{a}^{*}$ (redness), and $\mathrm{b}^{*}$ (yellowness) values, shear force, thawing and cooking losses, and chemical composition of meat ( $p>0.05$ ). The $b^{*}$ (yellowness) value of subcutaneous fat was higher in steers fed corn, regardless of grain processing $(\mathrm{p}=0.03)$. Sarcomere length was higher in aged meat of steers fed sorghum, regardless of processing method $(\mathrm{p}=0.01)$. Conclusions: the grain processing method does not affect beef quality; however, grain type can affect subcutaneous fat color and sarcomere length of aged beef.
\end{abstract}

Keywords: beef; bovine; cattle; corn; ensiled grain; grain; maize; marbling; meat color; meat quality; Nellore; sarcomere; silage; sorghum; subcutaneous fat; zebu.

Received: August 21, 2018; accepted: September 10, 2019

* Corresponding Author. Petrolina, Pernambuco 56304-917, Brasil. Tel.: +55-87-21014845. E-mail: rafaeltsrodrigues@gmail.com 


\section{Resumen}

Antecedentes: La rehidratación de granos, tales como maíz y sorgo, se usa para aprovechar mejor sus nutrientes. Sin embargo, es poco conocido el efecto de esta práctica sobre la calidad de la carne. Objetivo: Evaluar los efectos del tipo de cereal y su procesamiento sobre la calidad de carne de toretes Nelore en confinamiento. Métodos: Veinticuatro novillos Nelore enteros con un peso promedio inicial de $270 \pm 53 \mathrm{~kg}$, se distribuyeron en un diseño factorial $2 \times 2$ completamente aleatorizado $(n=6)$. El primer factor fue el tipo de cereal (maíz o sorgo) y el segundo fue su procesamiento (seco o rehidratado y ensilado). Las dietas estuvieron compuestas por $28,44 \%$ de ensilaje de maíz y $71,56 \%$ de concentrado. Sesenta días antes de iniciar el experimento, los granos de maíz y sorgo se rehidrataron y ensilaron. Los animales se sacrificaron después de 140 días de confinamiento. La calidad de la carne se determinó en muestras de carne fresca y madurada (7 días) obtenidas del músculo Longissimus lumborum. Resultados: No hubo diferencias entre tratamientos para el pH de las canales, ni para los valores de color (L* "luminosidad", a* "intensidad de rojo" y b* "intensidad de amarillo"), fuerza de corte, composición química, o pérdidas de agua por descongelamiento o cocción $(\mathrm{p}>0,05)$. El valor de $b^{*}$ de la grasa subcutánea fue mayor en los novillos alimentados con maíz, independientemente del tipo de procesamiento $(\mathrm{p}=0,03)$. La longitud de sarcómero fue más alto en la carne madurada de novillos alimentados con sorgo, sin importar el método de procesamiento ( $\mathrm{p}=0,01)$. Conclusiones: El método de procesamiento del grano no afecta la calidad de la carne; sin embargo, el tipo de cereal afecta el color de la grasa subcutánea y la longitud del sarcómero de la carne madurada.

Palabras clave: bovino; calidad de carne; carne; cebú; cereal; color de la carne; ensilado; ensilaje; ganado; grano; grano ensilado; grasa subcutánea; maíz; marmoreo; Nelore; sarcómero; sorgo.

\section{Resumo}

Antecedentes: A reidratação de grãos, como milho e sorgo, tem sido usada para aumentar a utilização de seus nutrientes. Contudo, o efeito dessa prática na qualidade da carne é pouco compreendido. Objetivo: Avaliar os efeitos do tipo de grão de cereais e seu processamento sobre a qualidade da carne de bovinos confinados. Métodos: Vinte e quatro bovinos Nelore não castrados, com peso corporal médio inicial de $270 \pm 53 \mathrm{~kg}$ foram distribuídos em delineamento inteiramente casualizado, fatorial $2 \times 2$, com seis repetições. O primeiro fator foi o tipo de grão de cereal no concentrado (milho ou sorgo), e o segundo foi o processamento destes grãos (seco ou reidratado e ensilado). As dietas foram compostas por $28,44 \%$ de silagem de milho e $71,56 \%$ de concentrado. Sessenta dias antes do início do experimento, os grãos de milho e sorgo foram reidratados e ensilados. Os animais foram abatidos após 140 dias de confinamento. As análises de qualidade da carne foram determinadas em amostras não maturadas e maturadas (7 dias) obtidas do músculo Longissimus lumborum. Resultados: Não houve diferenças significativas $(\mathrm{p}>0,05)$ entre os tratamentos para $\mathrm{pH}$ da carcaça e L* (luminosidade), a* (intensidade de vermelho), $\mathrm{b}^{*}$ (intensidade de amarelo), força de cisalhamento, perdas por descongelamento, perdas por cocção, perdas totais e composição química da carne. $\mathrm{O}$ valor de $\mathrm{b}^{*}$ da gordura subcutânea foi maior $(\mathrm{p}=0,03)$ em bovinos alimentados com dietas contendo grãos de milho, independentemente do tipo de processamento. O comprimento de sarcômero foi maior na carne maturada de novilhos alimentados com sorgo, independente do método de processamento $(\mathrm{p}=0,01)$. Conclusões: $\mathrm{O}$ método de processamento dos grãos não afetou a qualidade da carne bovina, no entanto, a cor da gordura subcutânea e o comprimento de sarcômero da carne maturada foram afetados pelo tipo de grão.

Palavras-chave: bovino; color da carne; gado; gordura subcutânea; grão; grão ensilado; marmoreio; milho; Nelore; qualidade de carne; sarcômero; sorgo; zebuíno. 


\section{Introduction}

Brazil is the largest beef exporter (USDA, 2018). Corn and sorghum grains are the main starch sources used for Brazilian steers in feedlots (Oliveira and Millen, 2014). However, both cereals have a strong protein matrix around the starch granules, limiting ruminal and intestinal digestion. This problem is aggravated in Brazil, where most corn hybrids have a hard endosperm, rich in protein matrix (Costa et al., 2014). Grain rehydration and subsequent ensiling can be used to increase starch digestibility by reducing the protein matrix integrity, providing greater access for microbes and intestinal enzymes to the starch granules (Arcari et al., 2016).

High digestibility of starch is a prerequisite for increasing glucose uptake, either indirectly, through gluconeogenesis -which uses propionate as the main substrate- or directly through glucose uptake in the small intestine (Rowe et al., 1999). Glucose is used in muscle for glycogen synthesis, which plays a key role in the decline of post-mortem muscle $\mathrm{pH}$ when converted to lactic acid and hydrogen protons (Volpi-Lagreca and Duckett, 2017). A muscular drop in $\mathrm{pH}$ is of great importance for meat quality traits, such as color, water retention capacity and tenderness (Ferguson and Gerrard, 2014). Moreover, glucose is the preferred substrate for the synthesis of intramuscular fat (Smith and Crouse, 1984; Rhoades et al., 2007; Smith et al., 2009).

Although it is well known that rehydration of cereal grains has positive effects on animal performance, to the best of our knowledge no studies have evaluated its effects on meat quality. Thus, our hypothesis was that corn and sorghum rehydration could affect beef quality. Therefore, the aim of this study was to evaluate the effects of two cereals and rehydration on meat quality of Nellore steers in a feedlot.

\section{Materials and methods}

\section{Ethical considerations}

All animal procedures were approved by the
Animal Care and Use Committee of Universidade Federal de Viçosa (CEUAP), Brazil, protocol number 29/2017.

\section{Animals and treatments}

Twenty-four non-castrated Nellore steers with $270 \pm 53 \mathrm{~kg}$ initial body weight and 7 months of age were used. All animals were identified, weighed and dewormed (Ivermectin 1\%, Merial, Paulínia, SP, Brazil; $1 \mathrm{ml}$ per 50 $\mathrm{kg}$ body weight) at the beginning of the trial. The treatments were cereal grain type (corn or sorghum) and grain processing method (dry or rehydrated and ensiled), which were offered in the concentrate.

\section{Grain rehydration and ensiling}

Corn and sorghum grains were rehydrated sixty days before the beginning of the experiment. A total of $6000 \mathrm{~kg}$ of each grain were ground in a hammer mill through a 3-mm screen. Then, samples were collected to determine dry matter content of the ground material. Subsequently, water was added to the ground material until $35 \%$ moisture was reached, using a concrete mixer for homogenization. The ground and rehydrated grains were ensiled in horizontal concrete silos at an approximate density of $1000 \mathrm{~kg} / \mathrm{m}^{3}$. Silos were covered with plastic canvas, and a $10 \mathrm{~cm}$ sand layer was placed on the canvas.

\section{Diets and chemical analysis}

The diets were isoproteic and formulated according to the BR-CORTE for $1.2 \mathrm{~kg}$ gain per day (Valadares Filho et al., 2010). The diets were composed of $28.44 \%$ corn silage and $71.56 \%$ concentrate (Table 1). The samples of corn silage and concentrates were analyzed for dry matter (INCT-CAG-003/1 method), ash (INCTCA M-001/1 method), crude protein (INCTCA N-001/1 method), ether extract (INCT-CA G-005/1 method), neutral detergent fiber (INCTCA F-002/1 method) and non-fiber carbohydrates according to Detmann et al. (2012). 
Table 1. Ingredients and chemical composition of the experimental diets.

\begin{tabular}{|c|c|c|c|c|}
\hline \multirow{3}{*}{ Ingredients (g/kg dry matter) } & \multicolumn{4}{|c|}{ Treatments } \\
\hline & \multicolumn{2}{|c|}{ Corn grain } & \multicolumn{2}{|c|}{ Sorghum grain } \\
\hline & Dry & Rehydrated & Dry & Rehydrated \\
\hline Corn silage & 284.4 & 284.4 & 284.4 & 284.4 \\
\hline Dry corn & 608.3 & - & - & - \\
\hline Rehydrated ensiled corn & - & 608.3 & - & - \\
\hline Dry sorghum & - & - & 608.3 & - \\
\hline Rehydrated ensiled sorghum & - & - & - & 608.3 \\
\hline Soybean meal & 67.5 & 67.5 & 67.5 & 67.5 \\
\hline Mineral mix ${ }^{a}$ & 29.4 & 29.4 & 29.4 & 29.4 \\
\hline Urea + Ammonium sulfate ${ }^{b}$ & 10.4 & 10.4 & 10.4 & 10.4 \\
\hline \multicolumn{5}{|l|}{ Composition ( $\mathrm{g} / \mathrm{kg}$ dry matter) } \\
\hline Dry matter & 542.1 & 467.4 & 541.7 & 473.2 \\
\hline Organic matter & 958.8 & 964.5 & 961.2 & 964.1 \\
\hline Crude protein & 133.6 & 131.0 & 133.7 & 130.5 \\
\hline Ether extract & 29.6 & 36.1 & 19.4 & 26.5 \\
\hline Neutral detergent fiber & 238.4 & 208.4 & 239.2 & 219.2 \\
\hline Non-fiber carbohydrates & 557.2 & 589.0 & 569.0 & 588.0 \\
\hline
\end{tabular}

${ }^{a}$ Mineral mix: 150 g Ca; 17 g P; 23 g S; 45 g K; 14 g Mg; 57 g Na; 360 mg Cu; 21.6 mg Co; 415 mg Fe; 21 mg I; 715 mg Mn; $6 \mathrm{mg} \mathrm{Se} ; 714 \mathrm{mg}$ monensin sodium.

${ }^{b}$ 9:1 urea to ammonium sulfate ratio.

\section{Animal management and slaughter}

After 28 days of adaptation, the steers were confined for 140 days in individual covered stalls with concrete floor, water supply and mangers for feeding. The animals were fed twice a day, at 0700 and $1500 \mathrm{~h}$, allowing no more than $10 \%$ orts. Silage and concentrate were mixed directly in the manger. Cattle slaughtering was carried out according to animal welfare regulations (MAPA, 2000).

\section{Carcass temperature and $\mathrm{pH}$ measurements}

After skinning and evisceration, the carcasses were stored in a cold room at $4{ }^{\circ} \mathrm{C}$ for $24 \mathrm{~h}$. Temperature and $\mathrm{pH}$ were measured in the Longissimus lumborum muscle every $2 \mathrm{~h}$ using a potentiometer (SevenGoTM, Mettler ToledoSchwerzenbach, Switzerland).

\section{Collection of meat samples}

Meat quality was determined in fresh and aged meat ( 7 days). After the cooling period, $L$. lumborum muscle samples were collected. Then, two one-inch thick steaks were vacuum-packed, one being immediately frozen (fresh meat) and the other aged for seven days at $4{ }^{\circ} \mathrm{C}$ and then frozen at $-20{ }^{\circ} \mathrm{C}$ (aged meat).

\section{Meat color measurement}

Color of subcutaneous fat on L. lumborum muscle was determined immediately aftercarcass cooling. For color analyses, steak samples were thawed at $4{ }^{\circ} \mathrm{C}$ for $16 \mathrm{~h}$. Before analysis, steaks were removed from the packages and exposed to oxygen for $30 \mathrm{~min}$. Color readings were obtained with a Hunter MiniScan EZ spectrophotometer (4500L, Hunter Associates Laboratory, Inc., Reston, VA, USA) using illuminant D65, a 31.8 
$\mathrm{mm}$ port size and a $10^{\circ}$ standard observer. The $\mathrm{L}^{*}$ (lightness), $\mathrm{a}^{*}$ (redness) and $\mathrm{b}^{*}$ (yellowness) values were calculated according to the CIELab scale and represented the means of five spectrophotometer readings at specific points on the sample surface.

\section{Thawing, weight loss, and shear force}

Thawing loss was calculated as the weight difference of steaks before and after thawing for $16 \mathrm{~h}$ at $4{ }^{\circ} \mathrm{C}$. Cooking loss was the weight difference before and after cooking in a water bath at $80{ }^{\circ} \mathrm{C}$ for $60 \mathrm{~min}$. Total loss was the weight difference between frozen and cooked steaks (AMSA, 2015).

Shear force measurements were performed on the same steaks used to estimate cooking losses. Five cylindrical samples $1.27 \mathrm{~cm}$ in diameter were collected from each steak, parallel to the orientation of the muscle fibers. The samples were sheared perpendicular to muscle fiber orientation using a $\mathrm{V}$-shaped cutting blade at a $60^{\circ}$ angle, at $1.016-\mathrm{mm}$ thickness and at a fixed rate of $20 \mathrm{~cm} / \mathrm{min}$, coupled with a WarnerBratzler machine (GR Electrical Manufacturing Company, Manhattan, KS, USA).

\section{Sarcomere length}

The sarcomere length was estimated according to the laser diffraction technique (Cross et al., 1981). Six thin filaments were removed from the thawed steak samples parallel to the orientation of the muscle fibers, which were placed separately on a glass slide. One drop of sucrose solution $(0.2$ $\mathrm{M}$ sucrose and $0.1 \mathrm{M} \mathrm{NaHPO}$ buffer at $\mathrm{pH} 7$ ) at $4^{\circ} \mathrm{C}$ was placed on each filament. Then, the slides were placed in a holder where the laser $(632.8$ $\mathrm{nm})$ was focused on the filaments using a heliumneon laser (Model 05-LHR-021, MelleGriot, Carlsbad, CA, USA). The diffraction bands were taken at $12 \mathrm{~cm}$ below the holder. Six diffraction bands were obtained for each sample and the mean value was used.

\section{Statistical analysis}

Data were analyzed using the Statistic Analysis System, version 9.1 (SAS Institute, Cary, NC, USA, 2003). The following statistical model was used: $Y=\mu+\alpha+\beta+\alpha \beta+$ e, where $\mu=$ mean, $\alpha=$ effect of grain type, $\beta=$ effect of processing, $\alpha \beta=$ interaction between grain type and processing, and $\mathrm{e}=$ random error. The experiment was conducted in a $2 \times 2$ factorial design and animals were randomly divided into 4 groups, 6 animals in each group. The first factor was cereal grain type in concentrate (corn or sorghum), and the second one was grain processing (dry or rehydrated and ensiled). The Tukey's test was used to compare means between treatments. Statistical differences were considered at $\mathrm{p}<0.05$.

\section{Results}

There was no effect ( $p>0.05)$ of grain type, processing or interaction between these factors on the carcass $\mathrm{pH}$ during the 24 hours of cooling (Table 2).

Treatments did not affect $(p>0.05)$ meat color parameters ( $\mathrm{L}^{*}, \mathrm{a}^{*}$ and $\left.\mathrm{b}^{*}\right)$ in both fresh or aged steaks (Table 3 ). However, offered corn grain diets had a higher $(p=0.03)$ intensity of yellow $\left(b^{*}\right)$ in subcutaneous fat compared to those containing sorghum grain, regardless of processing type (Table 3 ).

There were no differences $(\mathrm{p}>0.05)$ between treatments for shear force, thawing, cooking and total losses in fresh or aged steaks (Table $4)$. Sarcomere length was higher $(p=0.01)$ in the aged meat of steers fed sorghum, regardless of the processing method (Table 4).

There were no effects $(p>0.05)$ of cereal grain type, their processing nor interaction between them on the chemical composition of beef (Table 5). 
Table 2. Average $\mathrm{pH}$ of Longissimus lumborum muscle evaluated at different postmortem times in carcasses of steers fed corn (dry or rehydrated) or sorghum (dry or rehydrated) grain.

\begin{tabular}{|c|c|c|c|c|c|c|c|c|}
\hline \multirow{3}{*}{$\begin{array}{l}\text { Postmortem } \\
\text { times }\end{array}$} & \multicolumn{4}{|c|}{ Treatments } & \multirow{3}{*}{ SEM } & \multirow{2}{*}{\multicolumn{3}{|c|}{ p-value }} \\
\hline & \multicolumn{2}{|c|}{ Corn grain } & \multicolumn{2}{|c|}{ Sorghum grain } & & & & \\
\hline & Dry & Rehydrated & Dry & Rehydrated & & G & $\mathbf{P}$ & $\mathbf{G} \times \mathbf{P}$ \\
\hline 0 & 7.09 & 6.98 & 6.82 & 6.95 & 0.11 & 0.25 & 0.96 & 0.36 \\
\hline 2 & 6.80 & 6.79 & 6.66 & 6.58 & 0.16 & 0.17 & 0.73 & 0.76 \\
\hline 4 & 6.60 & 6.58 & 6.52 & 6.40 & 0.13 & 0.21 & 0.53 & 0.61 \\
\hline 6 & 6.41 & 6.47 & 6.36 & 6.22 & 0.15 & 0.20 & 0.74 & 0.39 \\
\hline 8 & 6.30 & 6.31 & 6.34 & 6.13 & 0.14 & 0.53 & 0.38 & 0.32 \\
\hline 10 & 6.30 & 6.22 & 6.13 & 6.02 & 0.12 & 0.86 & 0.33 & 0.06 \\
\hline 12 & 6.04 & 6.15 & 5.96 & 5.94 & 0.13 & 0.12 & 0.77 & 0.53 \\
\hline 14 & 5.97 & 6.06 & 5.95 & 5.89 & 0.13 & 0.33 & 0.89 & 0.46 \\
\hline 16 & 5.94 & 5.95 & 5.85 & 5.83 & 0.14 & 0.33 & 0.85 & 0.86 \\
\hline 18 & 5.84 & 5.93 & 5.77 & 5.80 & 0.13 & 0.32 & 0.55 & 0.78 \\
\hline 20 & 5.79 & 5.87 & 5.75 & 5.78 & 0.12 & 0.53 & 0.61 & 0.80 \\
\hline 22 & 5.78 & 5.86 & 5.74 & 5.68 & 0.15 & 0.37 & 0.96 & 0.55 \\
\hline 24 & 5.74 & 5.81 & 5.82 & 5.77 & 0.16 & 0.90 & 0.93 & 0.60 \\
\hline
\end{tabular}

SEM $=$ standard error of the mean.

p-value: $\mathrm{G}=$ effect of grain type; $\mathrm{P}=$ effect of grain processing; $\mathrm{G}$ x $\mathrm{P}=$ grain type by processing interaction.

Table 3. Average values of lightness $\left(\mathrm{L}^{*}\right)$, redness $\left(\mathrm{a}^{*}\right)$ and yellowness $(* \mathrm{~b})$ in the fresh or aged steaks and in the subcutaneous fat of steers fed corn (dry or rehydrated) or sorghum (dry or rehydrated) grain.

\begin{tabular}{|c|c|c|c|c|c|c|c|c|}
\hline \multirow{3}{*}{$\begin{array}{c}\text { Color } \\
\text { parameters }\end{array}$} & \multicolumn{4}{|c|}{ Treatments } & \multirow{3}{*}{ SEM } & \multirow{2}{*}{\multicolumn{3}{|c|}{ p-value }} \\
\hline & \multicolumn{2}{|c|}{ Corn grain } & \multicolumn{2}{|c|}{ Sorghum grain } & & & & \\
\hline & Dry & Rehydrated & Dry & Rehydrated & & $\mathbf{G}$ & $\mathbf{P}$ & $\mathbf{G} \times \mathbf{P}$ \\
\hline \multicolumn{9}{|c|}{ Fresh steak } \\
\hline $\mathrm{L}^{*}$ & 41.1 & 43.0 & 41.7 & 41.5 & 1.13 & 0.15 & 0.35 & 0.45 \\
\hline$a^{*}$ & 12.4 & 13.2 & 12.8 & 13.4 & 0.44 & 0.80 & 0.81 & 0.10 \\
\hline$b^{*}$ & 13.3 & 11.6 & 12.3 & 12.7 & 0.60 & 0.66 & 0.28 & 0.11 \\
\hline \multicolumn{9}{|c|}{ Aged steak (7 days postmortem) } \\
\hline $\mathrm{L}^{*}$ & 41.7 & 41.7 & 43.2 & 43.3 & 1.15 & 0.64 & 0.08 & 0.08 \\
\hline$a^{*}$ & 12.7 & 12.1 & 13.3 & 12.4 & 0.81 & 0.55 & 0.38 & 0.89 \\
\hline$b^{*}$ & 12.6 & 13.9 & 12.7 & 13.6 & 0.66 & 0.87 & 0.11 & 0.74 \\
\hline \multicolumn{9}{|c|}{ Subcutaneous fat } \\
\hline $\mathrm{L}^{*}$ & 66.6 & 68.1 & 70.4 & 64.9 & 1.97 & 0.89 & 0.32 & 0.09 \\
\hline$a^{*}$ & 10.2 & 11.2 & 8.6 & 10.3 & 1.06 & 0.26 & 0.21 & 0.75 \\
\hline$b^{*}$ & 23.4 & 23.4 & 22.5 & 21.1 & 0.69 & 0.03 & 0.33 & 0.32 \\
\hline
\end{tabular}

$\mathrm{SEM}=$ standard error of the mean.

p-value: $\mathrm{G}=$ effect of grain type; $\mathrm{P}=$ effect of grain processing; $\mathrm{G}$ x $\mathrm{P}=$ grain type by processing interaction. 
Table 4. Average values of shear force, sarcomere length, thawing, cooking and total losses in fresh or aged steaks of steers fed corn (dry or rehydrated) or sorghum (dry or rehydrated) grain.

\begin{tabular}{|c|c|c|c|c|c|c|c|c|}
\hline \multirow{3}{*}{ Aging period } & \multicolumn{4}{|c|}{ Treatments } & \multirow{3}{*}{ SEM } & \multirow{2}{*}{\multicolumn{3}{|c|}{ p-value }} \\
\hline & \multicolumn{2}{|c|}{ Corn grain } & \multicolumn{2}{|c|}{ Sorghum grain } & & & & \\
\hline & Dry & Rehydrated & Dry & Rehydrated & & $\mathbf{G}$ & $\mathbf{P}$ & $\mathbf{G} \times \mathbf{P}$ \\
\hline \multicolumn{9}{|c|}{ Shear force (kgf) } \\
\hline 0 day & 3.2 & 3.2 & 3.0 & 3.3 & 0.22 & 0.97 & 0.58 & 0.63 \\
\hline 7 days & 2.2 & 2.7 & 2.7 & 2.7 & 0.22 & 0.31 & 0.28 & 0.21 \\
\hline \multicolumn{9}{|c|}{ Sarcomere length $(\mu \mathrm{m})$} \\
\hline 0 day & 1.9 & 1.8 & 1.8 & 1.8 & 0.07 & 0.80 & 0.79 & 0.93 \\
\hline 7 days & 1.8 & 1.8 & 2.1 & 2.0 & 0.12 & 0.01 & 0.18 & 0.60 \\
\hline \multicolumn{9}{|c|}{ Thawing losses (\%) } \\
\hline 0 day & 4.2 & 4.1 & 3.7 & 3.7 & 1.26 & 0.72 & 0.99 & 0.96 \\
\hline 7 days & 5.2 & 4.1 & 3.1 & 4.2 & 1.06 & 0.34 & 0.97 & 0.31 \\
\hline \multicolumn{9}{|c|}{ Cooking losses (\%) } \\
\hline 0 day & 18.6 & 19.4 & 22.5 & 18.0 & 2.97 & 0.69 & 0.54 & 0.38 \\
\hline 7 days & 21.7 & 15.4 & 23.0 & 18.2 & 2.99 & 0.50 & 0.07 & 0.80 \\
\hline \multicolumn{9}{|c|}{ Total losses (\%) } \\
\hline 0 day & 22.8 & 23.6 & 26.2 & 21.7 & 3.33 & 0.82 & 0.58 & 0.45 \\
\hline 7 days & 21.4 & 20.4 & 20.8 & 19.1 & 1.16 & 0.77 & 0.13 & 0.60 \\
\hline
\end{tabular}

$\mathrm{SEM}=$ standard error of the mean.

p-value: $\mathrm{G}=$ effect of grain type; $\mathrm{P}=$ effect of grain processing; $\mathrm{G}$ x $\mathrm{P}=$ grain type by processing interaction.

Table 5. Average values of chemical composition of fresh steaks from steers fed corn (dry or rehydrated) or sorghum (dry or rehydrated) grain.

\begin{tabular}{|c|c|c|c|c|c|c|c|c|}
\hline \multirow{3}{*}{$\begin{array}{l}\text { Parameters } \\
\quad(\mathrm{g} / \mathrm{kg})\end{array}$} & \multicolumn{4}{|c|}{ Treatments } & \multirow{3}{*}{ SEM } & \multirow{2}{*}{\multicolumn{3}{|c|}{ p-value }} \\
\hline & \multicolumn{2}{|c|}{ Corn grain } & \multicolumn{2}{|c|}{ Sorghum grain } & & & & \\
\hline & Dry & Rehydrated & Dry & Rehydrated & & G & $\mathbf{P}$ & $\mathbf{G} \times \mathbf{P}$ \\
\hline Moisture & 786 & 796 & 809 & 792 & 1.16 & 0.41 & 0.76 & 0.25 \\
\hline Crude protein & 194 & 199 & 194 & 189 & 1.58 & 0.75 & 0.98 & 0.75 \\
\hline Ash & 10 & 9 & 9 & 10 & 0.07 & 0.92 & 0.94 & 0.07 \\
\hline Fat & 42 & 41 & 45 & 36 & 0.29 & 0.72 & 0.13 & 0.16 \\
\hline
\end{tabular}

$\mathrm{SEM}=$ standard error of the mean.

p-value: $\mathrm{G}=$ effect of grain type; $\mathrm{P}=$ effect of grain processing; $\mathrm{G} \times \mathrm{P}=$ grain type and processing interaction. 


\section{Discussion}

The final $\mathrm{pH}$ values, after 24 hours of cooling, were within the ideal range (5.5 to 5.8) for beef (Ferguson and Gerrard, 2014). Although diets with rehydrated grains provide high energy density, the lack of effect of grain processing on the rate of muscle $\mathrm{pH}$ decline could suggest that diets did not influence the synthesis and storage of muscle glycogen. The lack of effect of dietary energy density on $\mathrm{pH}$ drop has already been reported in ruminant carcasses (Immonen et al., 2000; Lowe et al., 2002; Apaoblaza et $a l ., 2017)$. This suggests that although dietary energy density has a strong impact on muscle glycogen synthesis (Pethick and Rowe, 1996; Frylinck et al., 2013), the relationship between muscle glycogen concentration and postmortem $\mathrm{pH}$ drop is not always linear since it is also dependent on the activity of enzymes involved in glycogenolysis (Apaoblaza et al., 2015). Similar to our study, the lamb carcass $\mathrm{pH}$ also did not differ between animals fed diets containing dry or ensiled high-moisture corn grain (Oliveira et al., 2015).

The lack of treatment effect on meat color parameters could be related to similar values of ultimate $\mathrm{pH}$ of carcasses in all experimental diets, which were within the ideal $\mathrm{pH}$ range $(\leq$ 5.8 ) to obtain a normal beef color (Mahmood et al., 2017). Oliveira et al. (2015) also did not observe differences in $L^{*}, a^{*}$ and $b^{*}$ parameters in meat of lambs fed dry or ensiled high-moisture corn.

The higher intensity of $b^{*}$ in the subcutaneous fat of steers fed corn diets could be due to a greater accumulation of carotenoids in these animals (Moloney et al., 2008; Rossi et al., 2016). Carotene and xanthophyll level in corn is 2.0 and $20.1 \mathrm{ppm}$, while it is 0.3 and $18.0 \mathrm{ppm}$ in sorghum, respectively. These carotenoids are related to yellow pigmentation in products of animal origin (Álvarez et al., 2015). Yellow color in subcutaneous fat is an undesirable characteristic in some southern European markets, which prefer whiter fat due to an association of yellow fat to low meat quality from older animals (Dunne et al., 2006). Therefore, the use of certain feeds with low capacity for pigmentation of subcutaneous fat, such as sorghum, could be an alternative to meet the demands of these stricter markets.

The tenderness values found in all treatments are within the range considered as tender meat (below $4.6 \mathrm{kgf}$; Shackelford et al., 1991) and have been reported in other studies under similar production system, genetic group and age (Igarasi et al., 2008; Rubiano et al., 2009).

The values found among all treatments analyzed for sarcomere length are within the natural variation $(1.3-2.1 \mu \mathrm{m})$ found in tender meat (Starkey et al., 2016). Postmortem sarcomere length interferes with meat tenderness, because a shorter sarcomere results in increased muscle fiber diameter and reduction in the area of action of proteolytic enzymes (Ertbjerg and Puolanne, 2017). Sarcomere length was higher in aged meat for 7 days of steers fed sorghum grain, regardless of the processing method. Proteolysis is the major structural change that occurs during meat aging, and can be related to increases in sarcomere length (Takahashi, 1999). Thus, differences in the activity of proteolytic enzymes such as calpain and cathepsins could be related to differences in sarcomere length between treatments.

The lack of grain type effect on thawing, cooking and total losses have already been reported by Igarasi et al. (2008), who evaluated the meat quality of steers fed wet corn or sorghum grains. Kazama et al. (2008) also did not observe effect of different types of energy concentrates on thawing and cooking losses in beef. Huck et al. (1998) and Gorocica-Buenfil et al. (2007) also did not observe differences in meat quality characteristics of cattle fed dry or high-moisture corn grain.

Moisture and protein in meat are relatively constant (approximately 75\% moisture and 
19 to $25 \%$ protein), with little influence of diet (Passini et al., 2002; Lage et al., 2012; Carvalho et al., 2014). The fat content found in the Longissimus muscle is correlated with intramuscular fat deposition, thus, fat content is a reliable marker of marbling (Bindon, 2004). The fat content found in all treatments was above the minimum $3 \%$ recommended to obtain the perception of meat flavor (Baghurst, 2004).

Glucose is the main substrate used in growing intramuscular adipocytes (Smith et al., 2009; Hocquete et al., 2010). Rehydration and ensiling of grains increase the digestibility of starch in the total digestive tract (Arcari et al., 2016), indirectly providing more substrate (propionate) through gluconeogenesis or directly (glucose) for the synthesis of intramuscular fat. Thus, the lack of grain processing effect on meat fat content was not expected, and this could be due to the low capacity of intramuscular fat deposition in non-castrated males (Bong et al., 2012; Baik et al., 2014), as well as the absence of genetic predisposition of Nellore steers for deposition of intramuscular fat (Teixeira et al., 2017).

The inability to increase gluconeogenic precursors to promote changes in fat content in the $L$. dorsi muscle of non-castrated Nellore steers has already been shown in studies in which intramuscular fat deposition was not affected by inclusion of crude glycerin (glyconeogenic precursor) in diet (Lage et al., 2014; San Vito et al., 2015).

In conclusion, neither the processing method of the grain nor its interaction with cereal type affected meat quality characteristics of Nellore steers. Cereal grain only affected subcutaneous fat color, which was more yellow in steers fed corn, and sarcomere length of aged beef, which was higher in steers fed sorghum.

\section{Declarations}

Funding

We thank the Fundação de Amparo à Pesquisa do Estado de Minas Gerais (FAPEMIG), the Conselho Nacional de Desenvolvimento Científico e Tecnológico (CNPq), the Instituto Nacional de Ciência e Tecnologia (INCT-CA) and the Coordenação de Aperfeiçoamento de Pessoal de Nível Superior (CAPES) for providing financial support.

\section{Conflicts of interest}

The authors declare they have no conflicts of interest with regard to the work presented in this report.

\section{Author contributions}

Conceptualization: Mario L Chizzotti; Sebastião C Valadares-Filho. Data curation: Fabiano A Ferreira. Formal analysis: Mario L Chizzotti; Fabiano A Ferreira; Germán D R Zamudio; Mauricio M Estrada; Marcos VC Pacheco; Breno C Silva. Funding acquisition: Mario L Chizzotti; Sebastião C Valadares-Filho. Investigation: Fabiano A Ferreira; Germán DR Zamudio; Mauricio M Estrada; Marcos VC Pacheco; Breno C Silva. Methodology: Mario L Chizzotti; Sebastião C Valadares-Filho; Fabiano A Ferreira; Germán DR Zamudio; Mauricio M Estrada; Marcos VC Pacheco; Breno C Silva. Project administration: Mario L Chizzotti; Fabiano A Ferreira. Resources: Mario L Chizzotti; Sebastião C Valadares-Filho. Supervision: Mario L Chizzotti; Sebastião C Valadares-Filho. Validation: Mario L Chizzotti; Fabiano A Ferreira. Visualization: Mario L Chizzotti; Fabiano A Ferreira. Writing - original draft: Fabiano A Ferreira; Rafael TS Rodrigues. Writing - review \& editing: Fabiano A Ferreira; Rafael TS Rodrigues. 


\section{References}

Álvarez R, Meléndez-Martínez AJ, Vicario IM, Alcalde MJ. Carotenoid and vitamin A contents in biological fluids and tissues of animals as an effect of the diet: A review. Food Rev Int 2015; 31 (4):319-340. DOI: https://doi.org/10.1080/87559129.2015.1015139

American Met Science Association (AMSA). Research guidelines for cookery, sensory evaluation, and instrumental tenderness measurements of meat. Champaign; 2015.

Apaoblaza A, Galaz A, Strobel P, Ramírez-Reveco A, Jeréz-Timaure N, Gallo C. Glycolytic potential and activity of adenosine monophosphate kinase (AMPK), glycogen phosphorylase(GP) and glycogen debranching enzyme (GDE) in steer carcasses with normal $(<5.8)$ or high $(>5.9) 24 \mathrm{~h} \mathrm{pH}$ determined in M. longissimus dorsi . Meat Sci 2015; 101:83-89. DOI: https://doi.org/10.1016/j.meatsci.2014.11.008

Apaoblaza A, Strobel P, Ramírez-Reveco A, Jeréz-Timaure N, Monti G, Gallo C. Effect of season, supplementation and fasting on glycolytic potential and activity of AMPactivated protein kinase, glycogen phosphorylase and glycogen debranching enzyme in grass-fed steers as determined in Longissimus lumborum muscle. Livest Sci 2017; 202:101-108. DOI:https://doi.org/10.1016/j.livsci.2017.05.028

Arcari M, Martins CMMR, Tomazi T, Goncalves JL, Santos M V. Effect of substituting dry corn with rehydrated ensiled corn on dairy cow milk yield and nutrient digestibility. Anim Feed Sci Technol 2016; 221:167-173. DOI: https://doi.org/10.1016/j.anifeedsci.2016.08.005

Baghurst K. Dietary fats, marbling and human health. Aust J Exp Agric 2004; 44(7):635-644. DOI: https://doi.org/10.1071/EA02140

Baik M, Jeong JY, Vu TTT, Piao MY, Kang H J. Effects of castration on the adiposity and expression of lipid metabolism genes in various fat depots of Korean cattle. Livest Sci 2014; 168:168-176. DOI: https://doi.org/10.1016/j.livsci.2014.08.013
Bindon BM. A review of genetic and non-genetic opportunities for manipulation of marbling. Aust J Exp Agric 2004; 44(7):687-696. DOI: https://doi.org/10.1071/EA02173

Bong JJ, Jeong JY, Rajasekar P, Cho YM, Kwon EG, Kim HC, Paek BH, Baik M. Differential expression of genes associated with lipid metabolism in Longissimus dorsi of Korean bulls and steers. Meat Sci 2012; 91(3):284-293. DOI: https://doi.org/10.1016/j.meatsci.2012.02.004

Carvalho JRR, Chizzotti ML, Ramos EM, Neto OM, Lanna DPD, Lopes LS, Teixeira PD, Ladeira MM. Qualitative characteristics of meat from young bulls fed different levels of crude glycerin. Meat Sci 2014; 96(2):977-983. DOI: https://doi.org/10.1016/j.meatsci.2013.10.020

Costa FMJ, Júnior GD, Zacaroni OF, Santos JF, Pereira RAN, Pereira MN. Silagem de grãos úmidosdemilhodetexturadura oumaciaemdietas com polpa cítrica para vacas em lactação. Arq Bras Med Vet Zootec 2014; 66(1):203-210. DOI: https://doi.org/10.1590/S0102-09352014000100028

Cross HR, West RL, Dutson TR. Comparison of methods for measuring sarcomere length in beef semitendinosus muscle. Meat Sci 1981; 5(4):261-266. DOI: $\underline{\text { https://doi.org/10.1016/0309-1740(81)90016-4 }}$

Detmann E, Souza MA, Valadares Filho SC, Queiroz AD, Berchielli TT, Saliba EOS, Cabral LS, Pina DS, Ladeira MM, Azevedo JAG. Métodos para Análise de Alimentos. Visconde do Rio Branco (MG): Suprema; 2012.

Dunne PG, O'mara FP, Monahan FJ, Moloney AP. Changes in colour characteristics and pigmentation of subcutaneous adipose tissue and M. Longissimus dorsi of heifers fed grass, grass silage or concentratebased diet. Meat Sci 2006; 74(2):231-241. DOI: https://doi.org/10.1016/j.meatsci.2006.02.003 
Ertbjerg P, Puolanne E. Muscle structure, sarcomere length and influences on meat quality: A review. Meat Sci 2017; 132:139-152. DOI: https://doi.org/10.1016/j.meatsci.2017.04.261

Ferguson DM, Gerrard DE. Regulation of post-mortem glycolysis in ruminant muscle. Anim Prod Sci 2014; 54(4):464-481. DOI: $\underline{\text { https://doi.org/10.1071/AN13088 }}$

Frylinck L, Strydom PE, Webb EC, Du TE. Effect of South African beef production systems on post-mortem muscle energy status and meat quality. Meat Sci 2013; 93(4):827-837. DOI: https://doi.org/10.1016/j.meatsci.2012.11.047

Gorocica-Buenfil MA, Fluharty FL, Bohn T, Schwartz SJ, Loerch, SC. Effect of low vitamin A diets with high-moisture or dry corn on marbling and adipose tissue fatty acid composition of beef steers. J Anim Sci 2007; 85(12):3355-3366. DOI: https://doi.org/10.2527/jas.2007-0172

Hocquette, JF, Gondret F, Baéza E, Médale F, Jurie C, Pethick DW. Intramuscular fat content in meat-producing animals: development, genetic and nutritional control, and identification of putative markers. Animal 2010; 4(2):303-319. DOI:https://doi.org/10.1017/S1751731109991091

Huck GL, Kreikemeier KK, Kuhl GL, Eck TP, Bolsen KK. Effects of feeding combinations of steam-flaked grain sorghum and steam-flaked, high-moisture, or dry-rolled corn on growth performance and carcass characteristics in feedlot cattle. J Anim Sci 1998; 76(12):2984-2990. DOI: https://doi.org/10.2527/1998.76122984x

Igarasi MS, Arrigoni MDB, Hadlich JC, Silveira AC, Martins CL, Oliveira HND. Características de carcaça e parâmetros de qualidade de carne de bovinos jovens alimentados com grãos úmidos de milho ou sorgo. Rev Bras Zootec 2008; 37(3):520-528. DOI: https://doi.org/10.1590/S1516-35982008000300018
Immonen K, Ruusunen M, Hissa K, Puolanne E. Bovine muscle glycogen concentration in relation to finishing diet, slaughter and ultimate $\mathrm{pH}$. Meat Sci 2000; 55(1):25-31. DOI: https://doi.org/10.1016/S0309-1740(99)00121-7

Kazama R, Zeoula LM, Prado IN, Silva DC, Ducatti T, Matsushita M. Características quantitativas e qualitativas da carcaça de novilhas alimentadas com diferentes fontes energéticas em dietas à base de cascas de algodão e de soja. Rev Bras Zootec 2008; 37(2):350-357. DOI: https://doi.org/10.1590/S1516-35982008000200023

Lage JF, Paulino PVR, Valadares Filho SC, Souza EJO, Duarte MS, Benedeti, PDB, Souza NK, Cox RB. Influence of genetic type and level of concentrate in the finishing diet on carcass and meat quality traits in beef heifers. Meat Sci 2012; 90(3):770-774. DOI: https://doi.org/10.1016/j.meatsci.2011.11.012

Lage JF, Berchielli TT, Vito ES, Silva RA, Ribeiro AF, Reis, RA, Dallantonia, EE, Simonetti LR, Delevatti LM, Machado M. Fatty acid profile, carcass and meat quality traits of young Nellore bulls fed crude glycerin replacing energy sources in the concentrate. Meat Sci 2014; 96(3):1158-1164. DOI: https://doi.org/10.1016/j.meatsci.2013.10.027

Lowe TE, Peachey BM, Devine CE. The effect of nutritional supplements on growth rate, stress responsiveness, muscle glycogen and meat tenderness in pastoral lambs. Meat Sci 2002; 62(4):391-397. DOI: https://doi.org/10.1016/S0309-1740(02)00027-X

Mahmood S, Roy BC, Larsen IL, Aalhus JL, Dixon WT, Bruce HL. Understanding the quality of typical and atypical dark cutting beef from heifersand steers. MeatSci2017; 133:75-85.DOI: https://doi.org/10.1016/j.meatsci.2017.06.010 
Ministério da Agricultura, Pecuária e Abastecimento (MAPA). Regulamento Técnico de Métodos de Insensibilização para o Abate Humanitário de Animais de Açougue. Brasília; 2000.

Moloney AP, Keane MG, Dunne PG, Mooney MT, Troy DJ. Effect of concentrate feeding pattern in a grass silage/concentrate beef finishing system on performance, selected carcass and meat quality characteristics. Meat Sci. 2008; 79(2):355-364. DOI: https://doi.org/10.1016/j.meatsci.2007.10.018

Oliveira CA, Millen DD. Survey of the nutritional recommendations and management practices adopted by feedlot cattle nutritionists in Brazil. Anim Feed Sci Technol 2014; 197:64-75. DOI: https://doi.org/10.1016/j.anifeedsci.2014.08.010

Oliveira LS, Mazon MR, Carvalho RF, Pesce DMC, Da Luz ESS, Gallo SB, Leme PR. Effects of processing corn on the carcass traits and meat quality of feedlot lambs. Trop Anim Health Prod 2015; 47(5):883-887. DOI: https://doi.org/10.1007/s11250-015-0803-X

PassiniR, SilveiraAC, TittoEAL, RodriguesPHM, Arrigoni MB, Costa C, Chardulo LAL. Silagem de grãos úmidos de milho e de sorgo e níveis protéicos sobre desempenho e características da carcaça de novilhos superprecoces. Acta Sci Anim Sci 2002; 24(4):1133-1140. DOI: https://doi.org/10.4025/actascianimsci.v24i0.2600

Pethick DW, Rowe JB. The effect of nutrition and exercise in carcass parameters and the level of glycogen in skeletal muscle of Merino sheep. Aust J Agric Res 1996; 47(4):525-537. DOI: https://doi.org/10.1071/AR9960525

Rhoades RD, Sawyer JE, Chung KY, Schell ML, Lunt DK, Smith SB. Effect of dietary energy source on in vitro substrate utilization and insulin sensitivity of muscle and adipose tissues of Angus and Wagyu steers. J Anim Sci 2007; 85(7):1719-1726. DOI: https://doi.org/10.2527/jas.2006-498
Rossi LG, Fiorentini G, Neto AJ, Vieira BR, Malheiros EB, Borghi TH, Berchielli TT. Impact of ground soybean and starch levels on the quality of meat from feedlot young Nellore bulls. Meat Sci 2016; 122:1-6. DOI: https://doi.org/10.1016/j.meatsci.2016.07.013

Rowe JB, Choct M, Pethick DW. Processing cereal grains for animal feeding. Aust J Agric Res 1999; 50(5):721-736. DOI: https://doi.org/10.1071/ar98163

Rubiano GAG, Arrigoni MDB, Martins CL, Rodrigues E, Gonçalves HC, Angerami CN. Desempenho, características de carcaça e qualidade da carne de bovinos superprecoces das raças Canchim, Nelore e seus mestiços. Rev Bras Zootec 2009; 38(12):2490-2498. DOI: https://doi.org/10.1590/S1516-35982009001200027

San Vito E, Lage JF, Ribeiro AF, Silva RA, Berchielli TT. Fatty acid profile, carcass and quality traits of meat from Nellore young bulls on pasture supplemented with crude glycerin. Meat Sci 2015; 100:17-23. DOI: https://doi.org/10.1016/j.meatsci.2014.09.008

SAS ${ }^{\circledR}$, Statistical Analisy System. SAS/STAT User's Guide. Version 9.1. Cary, NC: SAS Institute Inc; 2003.

Shackelford SD, Koohmaraie M, Miller MF, Crouse JD, Reagan JO. An evaluation of tenderness of the Longissimus muscle of Angus by Hereford versus Brahman crossbred heifers. J Anim Sci 1991; 69(1):171-177. DOI: https://doi.org/10.2527/1991.691171x

Smith SB, Crouse JD. Relative contributions of acetate, lactate and glucose to lipogenesis in bovine intramuscular and subcutaneous adipose tissue. J Nutr 1984; 114(4):792-800. DOI: https://doi.org/10.1093/jn/114.4.792

Smith SB, Kawachi H, Choi CB, Choi CW, Wu $\mathrm{G}$, Sawyer JE. Cellular regulation of bovine intramuscular adipose tissue development and composition. JAnim Sci2009; 87 (14 Suppl):72-82. DOI: https://doi.org/10.2527/jas.2008-1340 
Starkey CP, Geesink GH, Collins D, Oddy VH, Hopkins DL. Do sarcomere length, collagen content, $\mathrm{pH}$, intramuscular fat and desmin degradation explain variation in the tenderness of three ovine muscles? Meat Sci 2016; 113:51-58. DOI: https://doi.org/10.1016/j.meatsci.2015.11.013

Takahashi K. Tenderization mechanism of meat during post-mortem aging: The calcium theory of meat tenderization. Anim Sci J 1999; 70(1):1-11. DOI: https://doi.org/10.2508/chikusan.70.1

Teixeira PD, Oliveira DM, Chizzotti ML, Chalfun-Junior A, Coelho T C, Gionbelli M, Paiva LV, Carvalho JRR, Ladeira MM. Subspecies and diet affect the expression of genes involved in lipid metabolism and chemical composition of muscle in beef cattle. Meat Sci 2017; 133:110-118. DOI: https://doi.org/10.1016/j.meatsci.2017.06.009

United States Department of Agriculture (USDA). Livestock and poultry: world markets and trade. Washington, D.C; 2018.

Valadares Filho SC, Marcondes MI, Chizzotti ML, Paulino PVR. Nutrient Requirements of Zebu Beef Cattle-BR-CORTE. Visconde do Rio Branco (MG): Suprema; 2010.

Volpi-Lagreca G, Duckett SK. Supplementation of glycerol or fructose via drinking water to grazing lambs on tissue glycogen level and lipogenesis. J Anim Sci 2017; 95(6):2558-2575. DOI: https://doi.org/10.2527/jas.2017.1449 